\title{
Inoculante Enzimático-Bacteriano, Composição Química e Parâmetros Fermentativos das Silagens dos Capins Tanzânia e Mombaça ${ }^{1}$
}

\author{
Rogério Marchiori Coan ${ }^{2}$, Paulo de Figueiredo Vieira ${ }^{3}$, Roselene Nunes da Silveira², \\ Ricardo Andrade Reis ${ }^{3}$, Euclides Braga Malheiros ${ }^{3}$, Márcio dos Santos Pedreira ${ }^{2}$
}

\begin{abstract}
RESUMO - Objetivou-se, com o presente trabalho, avaliar os efeitos de idades de colheita e do uso de inoculante enzimático-bacteriano sobre os parâmetros de fermentação, de composição química e digestibilidade in vitro da matéria seca (DIVMS) das silagens dos cultivares Tanzânia e Mombaça (Panicum maximum Jacq.). As forragens foram colhidas aos 45 e 60 dias após o corte de uniformização, submetidas a dois tratamentos (A - Ensilagem sem aditivo [Controle]; B - Ensilagem com adição de inoculante enzimático-bacteriano) e distribuídas em um delineamento inteiramente casualizado em esquema fatorial (dois capins x duas inoculações x duas idades de corte), com três repetições. O conteúdo de MS das silagens confeccionadas com as plantas colhidas aos 60 dias de rebrota foi superior àquele das silagens colhidas com 45 dias. As silagens confeccionadas com as plantas colhidas aos 45 dias de rebrota apresentaram os maiores teores de PB $(11,9 \%)$. Não se observaram efeitos das silagens, dos tratamentos e das idades de corte sobre os teores de hemicelulose, celulose e DIVMS e valores de $\mathrm{pH}$ e $\mathrm{N}-\mathrm{NH}_{3}$. As silagens do capim-tanzânia apresentaram os maiores teores de MS, FDN, FDA, ácido lático e ácido butírico, enquanto as de capim-mombaça, os de PB e de ácido acético. A adição de inoculante enzimático-bateriano promoveu silagens com menores teores de MS, PB e lignina que as não-tratadas. Os capins tanzânia e mombaça não apresentaram limitações ao processo de ensilagem. O inoculante enzimático-bacteriano não melhorou as características qualitativas, fermentativas e nutricionais das silagens avaliadas.
\end{abstract}

Palavras-chave: aditivos, DIVMS, enzimas, idades de corte, Panicum maximum, $\mathrm{pH}$

\section{Enzymatic-Bacterial Inoculants, Chemical Composition and Fermentation Characteristics of Tanzaniagrass and Mombaçagrass Silages}

\begin{abstract}
The objective of this trial was to evaluate the effect of the harvest time (45 or 60 days of regrowth), and enzymaticbacterial inoculants on the fermentation characteristics, chemical composition, in vitro dry matter digestibility (IVDMD) of silages from Tanzânia and Mombaça (Panicum maximum Jacq.) cultivars. Forages, cut in the different ages, were ensiled according two treatments: A - Control; B - Ensiled with enzymatic-bacterial inoculants. A completely randomized experimental design was in a $2 \times 2 \times 2$ factorial arrangement (grass x inoculation x cutting ages) with three replications. The DM content of silages harvest ed at 60 days of regrowth showed higher values than that harvested at 45 days. The silages from 45 days of regrowth showed higher content of CP (11.9\%). Forage silages, cutting age and inoculant addition did not affect the content of hemicellulose, cellulose and IV DMD, and $\mathrm{pH}$ and $\mathrm{NH}_{3}-\mathrm{N}$ values. Tanzaniagrass showed higher DM, NDF, ADF, lactic acid and butyric acid contents, while Mombaçagrass, CP and acetic acid contents. Enzymatic-bacterial inoculant addition showed the lowest content of DM, CP and lignin as compared to no addition. Tanzaniagrass and Mombaçagrass did not show limitations to silage process. Enzymatic-bacterial inoculant did not improve the qualitative, fermentative and nutritional characteristics of evaluated silages.
\end{abstract}

Key Words: additives, cutting ages, enzymes, IVDDM, Panicum maximum, pH

\section{Introdução}

A substituição das tradicionais silagens de milho e sorgo pelas de capim no arraçoamento de bovinos vem despertando maior interesse de técnicos e pecuaristas, por minimizar os custos de produção, em razão da alta produtividade por unidade de área dos capins tropicais, sobretudo no período de maior oferta.
Nos sistemas de produção de bovinos em pastejo, os capins tanzânia e mombaça (Panicum maximum Jacq.) vem sendo utilizados como recurso para conservação de forragem na forma de silagem. No estádio vegetativo (45 dias) essas plantas apresentam elevada qualidade nutricional, mas possuem alto teor de umidade, associado ao elevado poder tampão (PT) e aos baixos teores de carboidratos solúveis (CHOsol.), fatores que interferem no processo fermentativo, impedindo o rápido decréscimo do $\mathrm{pH}$ e possibilitando

\footnotetext{
${ }^{1}$ Parte da Dissertação de Mestrado em Zootecnia do primeiro autor, apresentada à FCAVJ/UNESP. Pesquisa financiada pela CAPES. 2 Alunos de Doutorado do Programa de Pós-Graduação em Produção Animal da FCAVJ/UNESP (rogeriocoan@netsite.com.br).

3 Professores da Faculdade de Ciências Agrárias e Veterinárias - UNESP, Campus de Jaboticabal - SP.
} 
o desenvolvimento de fermentações indesejáveis (Woolford, 1984; McDonald et al., 1991).

De acordo com Woolford (1984), o potencial de uma planta para ensilagem é dependente do teor original de umidade, que deve ser de 66 a 72\%, do conteúdo de CHOsol. (acima de 8,0\% na matéria seca) e do baixo poder tampão (PT), que não deve oferecer resistência à redução do $\mathrm{pH}$ para valores de 3,8 a 4,0. Pereira \& Reis (2001) comentaram que o ideal para o processo de ensilagem é que a forragem apresente teores de matéria seca entre 35 e $45 \%$, sendo que para valores de 40 a $45 \%$ é recomendável que a forragem seja picada em partículas menores $(1,0$ a 2,0 cm), para melhor compactação.

Nesse sentido, grande variedade de aditivos tem sido recomendada, com o intuito de se garantir melhor qualidade das silagens. Entretanto, deve-se considerar a eficácia e viabilidade do aditivo.

Atualmente, os aditivos biológicos, inoculantes bacterianos, são compostos por bactérias ácido-láticas, adicionados ou não de enzimas (celulases, amilases e hemicelulases), e abrangem a classe com mais rápido desenvolvimento em todo o mundo. Estes aditivos foram classificados por Vilela (1998) como sendo estimulantes da fermentação e não-nutritivos. O princípio básico de atuação destes produtos consiste no aumento da disponibilidade de açúcares simples, via complexo enzimático, para que as bactérias tenham acesso a esses açúcares, incrementando, dessa forma, a produção de ácido lático e promovendo a queda brusca do $\mathrm{pH}$ (Lavezzo, 1993). A maioria dos inoculantes comerciais de silagem contém culturas vivas de Lactobacillus, Pedicoccus ou Streptococcus, com predominância das espécies Lactobacillus plantarum e/ou Streptococus faecium.

Diversos estudos têm sido realizados para avaliar o efeito dos inoculantes sobre a fermentação de várias forrageiras e, na maioria, notou-se favorecimento no declínio do $\mathrm{pH}$ e aumentos nos níveis de ácido lático (Bolsen, 1995). A eficiência dos inoculantes de silagem depende do nível de bactérias existentes na cultura, do poder tampão e da quantidade e qualidade dos microrganismos adicionados à cultura.

Em experimentos em que se acompanharam a dinâmica fermentativa de silagens inoculadas com lactobacilos, observou-se rápida elevação do número desses microrganismos, elevada produção de ácido lático, rápido declínio do $\mathrm{pH}$ e consumo de glicídeos solúveis em três a sete dias de fermentação (Kung Jr. et al., 1990; Bolsen et al., 1992). A aceleração do processo fermentativo e a rápida queda do $\mathrm{pH}$ têm sido responsáveis pela diminuição da desaminação, restringindo a proteólise (McDonald et al., 1991).

$\mathrm{O}$ efeito dos aditivos bacterianos também tem sido pouco evidenciado quando o número de lactobacilos epífiticos é muito elevado, como na cultura do milho, Zea mays (Bolsen et al., 1992). Outros fatores que explicam a falta de resposta à ação dos aditivos bacterianos têm sido a contaminação por solo e a adequada qualidade fermentativa da silagem controle, graças à elevada concentração de carboidratos solúveis e ao teor de matéria seca no volumoso de origem (Woolford, 1984).

O uso de inoculantes com lactobacilos e enzimas fibrolíticas visa associar os objetivos supracitados. Dessa forma, esperar-se-ia efeito aditivo. Entretanto, alguns autores têm encontrado efeito antagônico (Guim et al., 1995) ao passo que outros não têm encontrado diferenças tanto na qualidade fermentativa (Berto \& Mulbach, 1997), como na composição da fração glicídica.

Assim, neste trabalho, objetivou-se avaliar o efeito do inoculante enzimático-bacteriano na composição química e os parâmetros fermentativos das silagens dos capins tanzânia e mombaça (Panicum maximum Jacq.), colhidos em diferentes idades.

\section{Material e Métodos}

O experimento foi conduzido na Fazenda Planalto, no município de Conceição das Alagoas - MG em latossolo vermelho-amarelo, textura média, cuja análise do solo apresentou os seguintes valores: $\mathrm{pH}$ em $\mathrm{CaCl}_{2}: 5,4 ;$ M.O. $\left(\mathrm{g} / \mathrm{dm}^{3}\right): 12,0 ; \mathrm{P}$ (resina- $\mathrm{mg} / \mathrm{dm}^{3}$ ): 12,$0 ; \mathrm{K}\left(\mathrm{mmol}_{\mathrm{c}} / \mathrm{dm}^{3}\right): 0,6 ; \mathrm{Ca}\left(\mathrm{mmol}_{\mathrm{c}} / \mathrm{dm}^{3}\right): 13,0 ; \mathrm{Mg}$ $\left(\mathrm{mmol}_{\mathrm{c}} / \mathrm{dm}^{3}\right): 6,0 ; \mathrm{H}+\mathrm{Al}\left(\mathrm{mmol}_{\mathrm{c}} / \mathrm{dm}^{3}\right): 13,0 ; \mathrm{SB}$ $\left(\mathrm{mmol}_{\mathrm{c}} / \mathrm{dm}^{3}\right): 19,6 ; \mathrm{T}\left(\mathrm{mmol}_{\mathrm{c}} / \mathrm{dm}^{3}\right): 32,6 \mathrm{e} \mathrm{V} \%: 60,0$.

$\mathrm{O}$ solo foi preparado mediante aração e gradagem e, com base nos resultados da análise de solo, foram aplicados $350 \mathrm{~kg} / \mathrm{ha}$ a lanço da fórmula 00-20-20 (NPK) na semeadura.

Decorrido um período de 90 dias da semeadura dos capins tanzânia e mombaça (04/11/1999), procedeu-se ao corte de rebaixamento para padronização do stand, seguido de adubação de cobertura com $55 \mathrm{~kg}$ de N, na forma de uréia. Após 45 e 60 dias de crescimento (março e abril/2000), os capins foram cortados a $20 \mathrm{~cm}$ do solo e picados no tamanho de, aproximadamente, $1 \mathrm{~cm}$ com máquina forrageira rebocada. As condições climáticas no dia do corte foram caracterizadas por baixa umidade relativa e temperatura elevada.

A produção de matéria seca (PMS) foi estimada por meio da colheita da forragem produzida em uma 
área útil de $4 \mathrm{~m}^{2} \mathrm{e}$, em seguida, pesada no campo. Imediatamente após o corte das forrageiras, retirouse uma amostra de cada uma delas, que foi pesada e encaminhada à estufa de circulação forçada a $65^{\circ} \mathrm{C}$, por 72 horas, para a determinação dos teores de matéria seca, de acordo com Silva (1998). A seguir, foram tomadas amostras dos volumosos que foram devidamente identificadas e congeladas em freezer $\left(-15^{\circ} \mathrm{C}\right)$, para as posteriores determinações dos teores de carboidratos solúveis em Espectofotômetro (Mod. 2010), segundo Johnson et al. (1966), do poder tampão, conforme Playne \& McDonald (1966), e da matéria seca, de acordo com Silva (1998).

As forrageiras colhidas nas diferentes idades (45 e 60 dias) foram picadas e submetidas aos seguintes tratamentos: A (Controle) - ensilagem das forrageiras sem aditivo. B - Ensilagem das forrageiras com adição de inoculante enzimático-bacteriano (Bacto Silo C Tropical, da marca KATEC $\left.{ }^{\circledR}\right)$.

O inoculante Bacto Silo C Tropical é composto por enzimas (hemicelulase, celulase e amilase) e cepas tropicalizadas de Lactobacillus plantaruam, Enterococcus faecium e Pediococcus spp., garantindo uma viabilidade celular de $10^{9} \mathrm{UFC} / \mathrm{g}$ do produto.

É importante ressaltar que as forragens do tratamento A (Controle) não receberam adição de água ou placebo durante o processo de ensilagem. Nas forragens do Tratamento B, o aditivo foi aplicado na dosagem de $15 \mathrm{~g} / 100 \mathrm{~kg}$ de forragem verde, diluído em $100 \mathrm{ml}$ de água filtrada e aplicado com pulverizador costal. À medida que a forragem recebeu o inoculante, foi misturada de forma a permitir a distribuição homogênea do produto. Em seguida, foi realizada a ensilagem das forrageiras em sacos plásticos com capacidade de 20 litros (1,0 x 4 x 0,1 m), buscando-se densidade próxima de $500 \mathrm{~kg} / \mathrm{m}^{3}$, por meio da compactação manual dos silos, que foram armazenados em temperatura ambiente e sob proteção da luz solar e de chuvas. Após 60 dias, os silos foram abertos, e das silagens foram retiradas duas amostras. Uma das amostras foi pesada e seca em estufa com circulação forçada a $65^{\circ} \mathrm{C}$, por 72 horas.

As amostras secas foram processadas em moinho do tipo Willey, com peneira de 30 meshs, armazenadas em frascos plásticos, devidamente etiquetados, e, então, encaminhadas ao laboratório para posteriores determinações dos conteúdos de matéria seca (MS), proteína bruta (PB), fibra em detergente neutro (FDN), fibra em detergente ácido (FDA), celulose, hemicelulose (por diferença), lignina e digestibilidade in vitro da matéria seca (DIVMS), realizadas de acordo com Silva (1998).

Em outra porção da amostra, realizou-se a extração do suco da silagem em prensa hidráulica para determinação do pH, dos teores de nitrogênio amoniacal (N Amoniacal/ N total), segundo Tosi (1973), e de ácidos orgânicos (ácidos acético, propiônico, lático e butírico) por meio de cromatografia gasosa, segundo Bonassi (1977). Os dados obtidos foram analisados segundo o delineamento estatístico inteiramente casualizado, num esquema fatorial de tratamentos (duas forrageiras $\mathrm{x}$ duas idades de corte $\mathrm{x}$ duas inoculações) com três repetições, utilizando-se o procedimento GLM (SAS, 1985), e as médias foram comparadas pelo teste Tukey a 5\% de probabilidade.

\section{Resultados e Discussão}

Os dados referentes à produção de matéria seca (PMS) em um único corte, aos teores de matéria seca (MS) e de carboidratos solúveis (CHOsol.) e ao poder tampão (PT) dos capins tanzânia e mombaça no momento da ensilagem podem ser observados na Tabela 1. A análise dos dados evidenciou aumento na produção de matéria seca nas plantas colhidas aos 60 dias de rebrota, destacando-se a maior produção do capim-tanzânia colhido nessa idade.

Embora não tenha sido realizada a análise estatística, constatou-se aumentonumériconos teores de MS, CHOsol. e PT iguais a 10,21; 3,83 e 6,78\% para o capim-tanzânia e de 0,$41 ; 6,78$ e $15,56 \%$ para o capim-mombaça, com o avanço da idade de corte (45 para 60 dias).

De maneira geral, os capins tanzânia e mombaça apresentaram condições favoráveis à ensilagem nas diferentes idades (45 e 60 dias), no que se refere aos conteúdos de matéria seca e de carboidratos solúveis e ao poder tampão, tendo como parâmetro as recomendações de Woolford (1984), para obtenção de silagens de boa qualidade. Este autor preconizou que os teores de MS deveriam ser, no mínimo, de $25 \%$ e a relação poder tampão/carboidratos solúveis deveria ser no máximo de 3,0 para a obtenção de silagem de boa qualidade. Foram evidenciados teores de MS adequados $(28,4$ e $31,3 \%)$ para o capim-tanzânia e quase limitantes $(24,2$ e $25,1 \%)$ para o capim-mombaça com 45 e 60 dias de idade, respectivamente. Portanto, os valores $(1,68 ; 1,73 ; 1,46$ e 1,68$)$ encontrados para relação entre o poder tampão e os teores de carboidratos solúveis dos capins tanzânia e mombaça aos 45 e 60 dias de idade indicaram não haver limitações ao processo de ensilagem. 
Os teores de carboidratos solúveis e o poder tampão obtidos foram diferentes daqueles registrados por Bergamaschine et al. (1998) para o capim-tanzânia colhido aos 60 dias de crescimento e submetido ou não ao tratamento com inoculante enzimático-bacteriano (15,36 e 14,25\% CHOsol. na MS e 50,97 e 46,14 e.mg $\mathrm{HCl} / 100 \mathrm{~g} \mathrm{MS}$ ).

Em trabalho realizado com capim-elefante cv. Taiwan A-148 cortado com 48 dias de crescimento, Tosi et al. (1999) encontraram valores de 15,9\%, 23,23 e.mg HCL/100 g MS e 14,50\%, respectivamente, para os teores de matéria seca e carboidratos solúveis e para o poder tampão, com base na matéria seca.

A observação das características visuais, do odor e da textura das silagens evidenciou que o processo de fermentação ocorreu de maneira satisfatória em todas as silagens. Não foram observados desenvolvimentos de fungos, odor de amônia ou mesmo de forragem apodrecida nas silagens, que apresentaram coloração verde pardacenta, textura consistente e não pastosa após a abertura dos silos.

A análise comparativa dos dados de MS das plantas forrageiras (capins tanzânia e mombaça) no momento que antecede a ensilagem (Tabela 1) e de suas silagens (Tabela 2) evidencia valores próximos para esta variável nas diferentes idades avaliadas.

Observou-se interação entre idade de corte e capim, de modo que o capim-tanzânia apresentou teor de MS 11,0 e 23,6\% maiores que o capim-mombaça aos 45 e 60 dias de crescimento (Tabelas 2 e 3 ).
Pode-se inferir que a adição do inoculante enzimático-bacteriano às silagens promoveu decréscimo significativo $(\mathrm{P}<0,05)$ nos teores de MS das silagens avaliadas. Entretanto, o mesmo efeito não foi reportado por Bergamaschine et al. (1998), que observaram teores de 21,5 e $21,0 \%$ de MS para as silagens de capim-tanzânia colhido aos 60 dias de idade e submetido ou não à adição de inoculante enzimático-bacteriano.

A análise dos dados da Tabela 2 evidenciou teores mais elevados de $\mathrm{PB}(\mathrm{P}<0,05)$ nas silagens do capimmombaça $(11,7 \%)$ que nas silagens do capim-tanzânia $(10,9 \%)$. Nas silagens das plantas submetidas à adição do inoculante enzimático-bacteriano, observaram-se menores $(\mathrm{P}>0,05)$ teores de $\mathrm{PB}$. Os dados encontrados neste estudo contrariam os resultados obtidos por Bergamaschine et al. (1998) e Rocha et al. (2004), que observaram valores superiores de PB para as silagens de capim-tanzânia e capim-elefante aditivadas com inoculante enzimático-bacteriano.

Constatou-se, pela análise dos dados de FDN (Tabela 4), que as silagens dos capins tanzânia e mombaça apresentaram teores semelhantes de FDN aos 45 dias de colheita, enquanto aos 60 dias, as silagens do capim-tanzânia apresentaram teores $(77,3 \%)$ superiores $(\mathrm{P}<0,05)$ aos das silagens do capim-mombaça $(73,9 \%)$.

A análise dos dados de FDN (Tabela 4) das silagens dos capins tanzânia e mombaça colhidos aos 45 e 60 dias demonstra que não houve efeito significativo

Tabela 1 - Produção de matéria seca, teores de matéria seca, carboidratos solúveis e poder tampão dos capins tanzânia e mombaça no momento da ensilagem

Table 1 - Dry matter yield, dry matter content, water soluble carbohydrates content and buffering power of Tanzaniagrass and Mombaçagrass at the ensiling time

\begin{tabular}{|c|c|c|c|c|}
\hline \multirow{3}{*}{$\begin{array}{l}\text { Fração } \\
\text { Fraction }\end{array}$} & \multicolumn{4}{|c|}{$\begin{array}{l}\text { Capim } \\
\text { Grass }\end{array}$} \\
\hline & \multicolumn{2}{|c|}{$\begin{array}{l}\text { Tanzânia } \\
\text { Tanzania }\end{array}$} & \multicolumn{2}{|c|}{$\begin{array}{l}\text { Mombaça } \\
\text { Mombaça }\end{array}$} \\
\hline & $\begin{array}{l}45 \text { dias } \\
45 \text { days }\end{array}$ & $\begin{array}{l}60 \text { dias } \\
60 \text { days }\end{array}$ & $\begin{array}{l}45 \text { dias } \\
45 \text { days }\end{array}$ & $\begin{array}{l}60 \text { dias } \\
60 \text { days }\end{array}$ \\
\hline $\begin{array}{l}\text { Produção de MS (kg/ha) } \\
\text { Dry matter yield }\end{array}$ & $5.680,0$ & $12.019,2$ & $5.187,4$ & $9.914,5$ \\
\hline $\begin{array}{l}\mathrm{MS}(\%) \\
\operatorname{DM}(\%)\end{array}$ & 28,4 & 31,3 & 24,2 & 25,1 \\
\hline $\begin{array}{l}\text { Carboidratos solúveis (\% MS })^{1} \\
\text { Water soluble carbohydrates }\end{array}$ & 8,6 & 8,9 & 12,4 & 12,4 \\
\hline $\begin{array}{l}\text { Poder tampão } \\
\text { Buffering power }\end{array}$ & 14,4 & 15,4 & 18,1 & 20,9 \\
\hline
\end{tabular}

${ }^{1}$ Carboidratos solúveis (\% da MS) (Soluble carbohydrates (DM\%).

2 Poder tampão (e.mg HCl/100 g MS) (Buffering power (e.mg. HCl/100 g DM). 


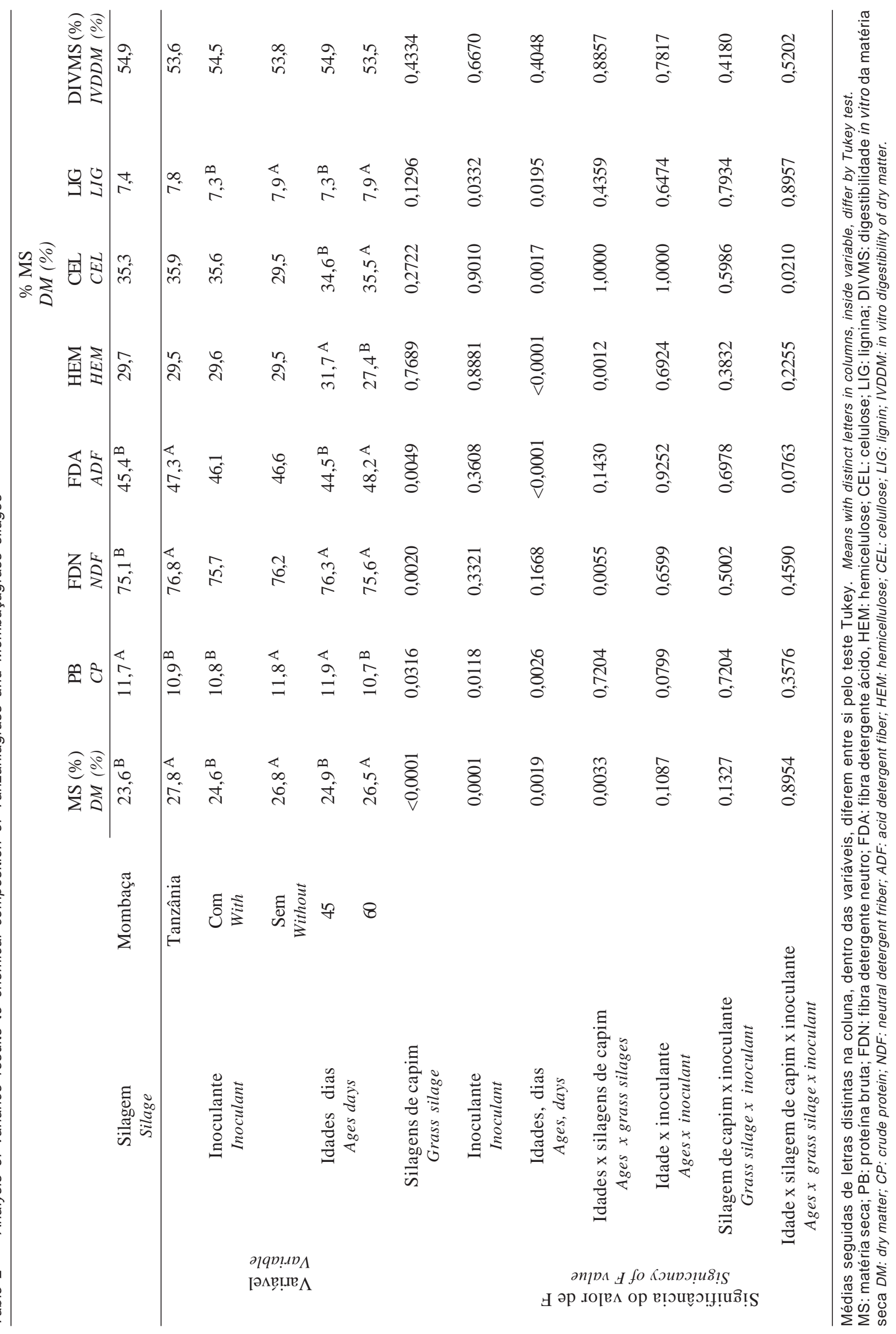


Tabela 3 - Comparação múltipla (Teste Tukey) para os teores de matéria seca da interação silagens $x$ idades de corte

Table 3 - Multiple comparison (Tukey test) for dry matter content of silage $x$ ages interaction

\begin{tabular}{lcc}
\hline $\begin{array}{l}\text { Silagem } \\
\text { Silage }\end{array}$ & \multicolumn{3}{c}{$\begin{array}{c}\text { Idades (dias) } \\
\text { Ages (days) }\end{array}$} \\
\cline { 2 - 3 } & \multicolumn{3}{c}{45} & 60 \\
\hline Mombaça & $23,6 \mathrm{Ba}$ & $23,7 \mathrm{Ba}$ \\
Tanzânia & $26,2 \mathrm{Ab}$ & $29,3 \mathrm{Ab}$ \\
\hline
\end{tabular}

Médias seguidas da mesma letra, minúsculas na linha e maiúsculas na coluna, não diferem entre si pelo teste Tukey.

Means with same letters, small in rows and capital in columns, do not differ by Tukey test.

$(\mathrm{P}>0,05)$ da idade de corte sobre esta variável, especificamente para as silagens do capim-tanzânia. As silagens do capim-mombaça observa-se que as silagens das plantas colhidas aos 45 dias apresentaram teores $(76,2 \%)$ mais elevados $(\mathrm{P}<0,05)$ de FDN que as silagens das plantas com 60 dias $(73,9 \%)$. Os resultados obtidos estão próximos daqueles observados por Bergamaschine et al. (1998), que encontraram valores de $73,7 \%$ para as silagens de capim-tanzânia com 60 dias de rebrota.

As silagens do capim-tanzânia apresentaram maiores teores $(\mathrm{P}<0,05)$ de FDA que as silagens do capimmombaça (Tabela 2). A utilização do inoculante não promoveu redução dos teores de FDA das silagens avaliadas, embora tenham sido observados teores de 46,1 e $46,6 \%$ para as silagens com e sem adição do inoculante. Este fato pode ser explicado pela ausência de atividade das enzimas presentes no inoculante enzimático-bacteriano em promover a solubilização dos constituintes da parede celular e aumentar a disponibilidade de carboidratos solúveis para fermentação pelas bactérias ácido-láticas. Os resultados obtidos neste

Tabela 4 - Comparação múltipla (teste Tukey) para os teores de fibra em detergente neutro (\% MS) da interação silagens $x$ idades de corte

Table 4 - Multiple comparison (Tukey test) for neutral detergent fiber (DM \%) contents of silage $x$ ages interaction

\begin{tabular}{lcc}
\hline $\begin{array}{l}\text { Silagem } \\
\text { Silage }\end{array}$ & \multicolumn{3}{c}{$\begin{array}{c}\text { Idade (dias) } \\
\text { Age (days) }\end{array}$} \\
\cline { 2 - 3 } & \multicolumn{3}{c}{45} & 60 \\
\hline Mombaça & $76,2 \mathrm{Aa}$ & $73,9 \mathrm{Bb}$ \\
Tanzânia & $76,4 \mathrm{Aa}$ & $77,3 \mathrm{Aa}$ \\
\hline
\end{tabular}

Médias seguidas de mesma letra, minúsculas na linha e maiúsculas na coluna, não diferem entre si pelo teste Tukey.

Means with same letters, small in rows and capital in columns, do not differ by Tukey test. estudo estão abaixo daqueles encontrados por Bergamaschine et al. (1998), que avaliaram a silagem de capim-tanzânia com 60 dias de rebrota e registraram valores de 51,32 e 50,07\% de FDA para as silagens confeccionadas come sem adição de inoculante bacteriano.

A partir da comparação dos teores de hemicelulose dos capins tanzânia e mombaça nas diferentes idades de corte (Tabela 5), observou-se que as silagens de capim-tanzânia apresentaram menores $(30,4 \%)$ e maiores $(28,5 \%)$ teores de hemicelulose que as silagens do capim-mombaça $(33,1$ e $26,2 \%)$ aos 45 e 60 dias, respectivamente.

Não houve diferenças estatísticas $(\mathrm{P}>0,05)$ entre os teores de celulose para as silagens confeccionadas com os capins tanzânia e mombaça submetidas ou não ao tratamento com inoculante enzimático-bacteriano (Tabela 2). As silagens com 60 dias de rebrota apresentaram maiores $(\mathrm{P}<0,05)$ teores de celulose que as silagens de forragens colhidas aos 45 dias. Constatouse, ainda, interação tripla entre os fatores analisados, que não foi discutida neste estudo por não apresentar mérito científico.

Não se observou diferença significativa $(\mathrm{P}>0,05)$ entre os teores de lignina (Tabela 2) as silagens dos capins tanzânia e mombaça. Por outro lado, as silagens adicionadas de inoculante enzimático-bacteriano apresentaram menores $(\mathrm{P}<0,05)$ teores de lignina, do mesmo modo que as silagens colhidas com 45 dias, que também apresentaram menores teores para esta variável.

A análise dos valores de digestibilidade in vitro da matéria seca (DIVMS) demonstrou não haver diferenças significativas entre as silagens dos capins tanzânia e mombaça, entre os diferentes tratamentos (com e sem inoculante) e as idades de colheita (45 e 60 dias)

Tabela 5 - Comparação múltipla (teste Tukey) para os teores de hemicelulose (\% MS) da interação silagens $\mathrm{x}$ idades de corte

Table 5 - Multiple comparizon (Tukey test) for hemicellulose $(D M \%)$ contents of silage $x$ ages interaction

\begin{tabular}{lcc}
\hline Silagem & \multicolumn{3}{c}{$\begin{array}{c}\text { Idade (dias) } \\
\text { Silage }\end{array}$} & \multicolumn{3}{c}{ Age (days) } \\
\cline { 2 - 3 } & 45 & 60 \\
\hline Mombaça & $33,1 \mathrm{Aa}$ & $26,2 \mathrm{Bb}$ \\
Tanzânia & $30,4 \mathrm{Aa}$ & $28,5 \mathrm{Aa}$ \\
\hline
\end{tabular}

Médias seguidas da mesma letra, minúsculas na linha e maiúsculas na coluna, não diferem entre si pelo teste Tukey.

Means with same letters, small in rows and capital in columns, do not differ by Tukey test. 
avaliadas (Tabela 2). No entanto, é importante ressaltar que os valores obtidos para as silagens com $(54,5 \%)$ e sem $(53,8 \%)$ adição do inoculante enzimáticobacteriano foram inferiores àqueles reportados por Bergamaschine et al. (2004), que ensilaram o capimtanzânia com 60 dias de crescimento com e sem a adição de aditivo enzimático-bacteriano e obtiveram valores de 60,23 e 58,72\% de DIVMS, respectivamente. De forma contrária, Bergamaschine et al. (1998) ensilaram o capim-tanzânia com adição de inoculante enzimático-bacteriano e encontraram valores de 34,22 e $31,65 \%$ de DIVMS, respectivamente.

Quanto aos valores de $\mathrm{pH}$ (Tabela 6), não ocorreram diferenças significativas $(\mathrm{P}>0,05)$ entre as silagens, entre os tratamentos (com e sem inoculante) e as diferentes idades de corte (45 e 60 dias). Os valores encontrados no presente estudo são semelhantes aos obtidos por Bergamaschine et al. (1998) e Rocha et al. (2004), que avaliaram as silagens dos capins tanzânia e elefante, especificamente.

McDonald et al. (1991) mencionaram que o limite máximo de $\mathrm{pH}$ para obtenção de silagens de qualidade satisfatória foi igual a 4,2. Dessa forma, as silagens avaliadas apresentaram valores superiores ao limite máximo. Em silagens convencionalmente conservadas, o pHelevado foi indicativo de grande produção de ácidos mais fracos, como o acético e butírico, oriundos de fermentações indesejáveis (Van Soest, 1994).

A análise dos dados (Tabela 6) referentes à concentração de $\mathrm{N}-\mathrm{NH}_{3}$ revelou não haver diferenças significativas $(\mathrm{P}>0,05)$ entre as variáveis avaliadas (silagens, inoculante e idades) no presente estudo. Os dados obtidos estão abaixo daqueles reportados por Ítavo et al. (1999), que estudaram a composição química e o padrão de fermentação das silagens de cinco gramíneas do gênero Cynodon (Tifton 44, Tifton 85, Coast Cross, Estrela de Porto Rico e Estrela Roxa) e registraram valores médios de $9,7 \%$ de $\mathrm{N}-\mathrm{NH}_{3}$ como porcentagem do $\mathrm{N}$ total.

Woolford (1984) e McDonald et al. (1991), na classificação quanto ao teor de nitrogênio amoniacal em relação ao nitrogênio total, consideraram a silagem como muito boa quando os valores foram inferiores a $10 \%$; aceitável de 10 a $15 \%$ e insatisfatória quando os valores se situaram acima de $20 \%$. Menores teores de nitrogênio amoniacal indicam menor intensidade de proteólise durante o processo de fermentação, em decorrência de menor atuação de bactérias do gênero Clostridium e, conseqüentemente, em menor produção de ácidobutírico (McDonald et al., 1991; Muck \& Shinners, 2001).
A análise dos dados referentes aos teores de ácidos orgânicos (Tabela 6) revelou maiores valores $(\mathrm{P}<0,05)$ de ácido lático para as silagens de capimtanzânia $(0,132 \%)$ que para as silagens do capimmombaça $(0,033 \%)$, enquanto o ácido acético foi significativamente $(\mathrm{P}<0,05)$ mais elevado nas silagens do capim-mombaça $(0,610 \%)$ que nas de capimtanzânia $(0,357 \%)$.

De acordo com McDonald et al. (1991), a elevada produção de ácido acético é indício da atuação de enterobactérias, que ocorrem durante os estádios iniciais da fermentação da silagem, competindo com as bactérias láticas por nutrientes. Esses microrganismos têm pouca atividade proteolítica, porém são capazes de degradar alguns aminoácidos, contribuindo para a produção de amônia e aminas biogênicas, a exemplo dos clostrídios. Segundo esses autores, o mecanismo de fermentação das enterobactérias é semelhante ao das bactérias heterofermentativas, ocasionando perdas de matéria seca e pequenas perdas de energia.

Para o ácido propiônico (Tabela 6), não foram observadas diferenças significativas $(\mathrm{P}>0,05)$ entre as silagens dos capins tanzânia e mombaça, da mesma forma que para os tratamentos (com e sem inoculante) e as idades de corte (45 e 60 dias).

As silagens do capim-tanzânia apresentaram maiores $(\mathrm{P}<0,05)$ teores de ácido butírico (Tabela 6) que as silagens de capim-mombaça. Não foi observado efeito significativo das variáveis inoculante e idades de corte sobre os teores de ácido butírico, ressaltando-se que os teores desse ácido nas silagens avaliadas foram inferiores àqueles estipulados por Woolford (1984), que preconizou nível menor que $0,2 \%$, na MS para que as silagens fossem caracterizadas como de boa qualidade.

Kung Jr. (2001) definiu que em silagens de capim tropicais, a proporção molar ideal dos ácidos orgânicos produzidos ao final do processo fermentativo deve ser de 6 a 10\% de ácido lático, 1 a 3\% de ácido acético, menor que $0,1 \%$ de ácido propiônico e igual a $0 \%$ de ácido butírico. A análise dos dados obtidos neste estudo demonstra que os teores dos ácidos lático e acético obtidos estão abaixo das recomendações desse autor, o que pode contribuir para a baixa capacidade de conservação da massa ensilada.

\section{Conclusões}

Os capins tanzânia e mombaça não apresentaram limitações ao processo de ensilagem, uma vez que os teores de matéria seca, carboidratos solúveis e o poder 


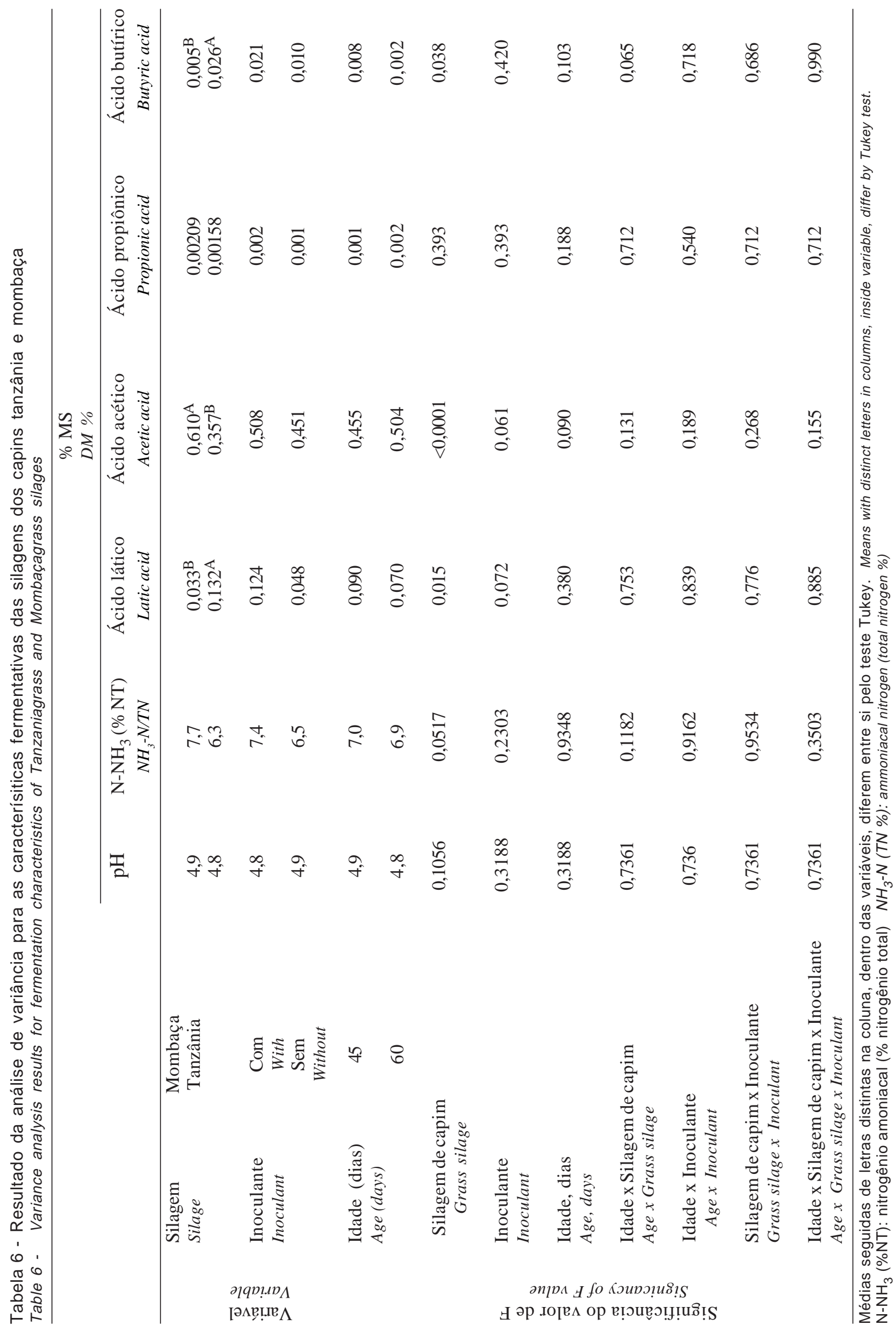


tampão foram pertinentes ao processo fermentativo, o que foi comprovado pelos baixos teores de nitrogênio amoniacal, e de moderados valores de $\mathrm{pH}$, embora o perfil de ácidos orgânicos das silagens fosse inadequado.

O capim-tanzânia colhido até os 60 dias de crescimento apresentou melhores condições para o processo de ensilagem, em função dos melhores parâmetros fermentativos e da composição química das silagens, quando comparado ao capim-mombaça.

Os resultados deste experimento indicam que o uso do inoculante enzimático-bacteriano não melhorou as características qualitativas, fermentativas e nutricionais das silagens avaliadas, independentemente da espécie forrageira e da idade de corte, não permitindo, assim, indicação de sua utilização nos sistemas de produção.

\section{Literatura citada}

BERGAMASCHINE, A.F.; VALÉRIO FILHO, W.V.; ISEPON, O.J. et al. Consumo e digestibilidade da silagem de capimcolonião ( $P$. maximum cv. Tanzânia) feita com aditivos ou emurchecimento. In: REUNIÃO ANUAL DA SOCIEDADE BRASILEIRA DE ZOOTECNIA, 41., 2004, Campo Grande. Anais... Campo Grande: Sociedade Brasileira de Zootecnia, [2004]. CD ROOM. Nutrição de Ruminantes. NR 068.

BERGAMASCHINE, A.F.; ISEPON, O.J.; GUATURA, A.S. et al. Efeitos da adição de resíduo de milho e da cultura enzimobacteriana sobre a qualidade da silagem do capim-tanzânia. In: REUNIÃO ANUAL DA SOCIEDADE BRASILEIRA DE ZOOTECNIA, 35., 1998, Botucatu. Anais... Botucatu: Sociedade Brasileira de Zootecnia, 1998. p.456.

BERTO, J.L.; MÜLBACH, P.R.F. Silagem de aveia preta no estádio vegetativo, submetida à ação de inoculantes e ao efeito do emurchecimento. Revista Brasileira de Zootecnia, v.26, n.4, p.651-658, 1997.

BOLSEN, K.K.; LIN, C.; BRENT, B.E. et al. Effect of silage additives on the microbial sucession and fermentation process of alfafa and corn silages. Journal of Dairy Science, v.75, n.11, p.3066-3083, 1992.

BOLSEN, K.K. Improving silage quality. Manhatan: Kansas State University, 1995. 40p.

BONASSI, I.A. Determinação de ácidos orgânicos em silagens por meio de cromatografia gasosa. (Adaptação do método de Wilson, 1971). Jaboticabal: Universidade Estadual Paulista, 1977. 40p. Dissertação (Mestrado em Zootecnia) - Universidade Estadual Paulista, 1977.

GUIM, A.; RUGGIERI, A.C.; ANDRADE, P. et al. Efeito de inoculante microbiano sobre consumo, degradação in situ e digestibilidade aparente das silagens de capim-elefante cv. Napier (Pennisetum purpureum Schum). Revista da Sociedade Brasileira de Zootecnia, v.24, n.6, p.1054-1061, 1995.

ÍTAVO, L.C.V.; GOMES, L.H.; JOBIM, C.C. et al. Composição e parâmetros da fermentação de silagens de gramíneas do genêro Cynodon. In: REUNIÃO ANUAL DA SOCIEDADE BRASILEIRA DE ZOOTECNIA, 36., 1999, Porto Alegre. Anais... Porto Alegre: Sociedade Brasileira de Zootecnia, [1999], CD-ROM.
JOHNSON, R.R.; BALWANI, T.L.; JOHNSON, L.J. et al. Corn plant maturity. II. Effect on "in vitro" cellulose digestibility and soluble carbohydrate content. Journal of Science Food and Agriculture, v.54, n.4, p.557-568, 1966.

KUNGJR., L.; MACIOROWKI, K; TUNG, R.S. A microbiological inoculant or glycopeptide antibiotic as silage additives. Journal of Dairy Science, v.73, p.175 (Suppl. 1), 1990.

KUNG JR., L. Aditivos microbianos e químicos para silagem: Efeitos na fermentação e resposta animal. In: WORKSHOP SOBRE MILHO PARA SILAGEM, 2., 2001, Piracicaba, Anais... Piracicaba: Fundação de Estudos Agrários Luiz de Queiroz, 2001. p.53-74.

LAVEZZO, W. Ensilagem de capim-elefante. In: SIMPÓSIO SOBRE MANEJO DA PASTAGEM, 10., 1992, Piracicaba. Anais... Piracicaba: Fundação de Estudos Agrários Luis de Queiroz, 1993. p.169.

McDONALD, P.; HENDERSON, N.; HERON, S. The biochemistry of silage. Marlow Bucks. Chalcombe Publications, 1991. 340p.

MUCK, R.E.; SHINNERS, K.J. Conserved forages (silage and hay): Progress and priorities. In: INTERNACIONAL GRASSLAND CONGRESS, 21., 2001, São Pedro. Proceedings... Piracicaba: Brazilian Society of Animal Husbandry, 2001. p.753.

PEREIRA, J.R.A.; REIS, R.A. Produção de silagem pré-secada com forrageiras temperadas e tropicais. In: SIMPÓSIO SOBRE PRODUÇÃO E UTILIZAÇÃO DE FORRAGENS CONSERVADAS, Maringá, 2001. Anais... Maringá: Universidade Estadual de Maringá, 2001. p.64.

PLAYNE, M.J.; McDONALD, P. The buffering constituints of herbage and of silage. Journal Science Food and Agriculture, v.17, p.264-268, 1966.

ROCHA, K.B.; PEREIRA, O.G.; GARCIA, R. et al. Composição química e digestibildiade in vitro de silagens de capim-elefante produzidas com inoculantes enzimo-bacterianos. In: REUNIÃO ANUAL DA SOCIEDADE BRASILEIRA DE ZOOTECNIA, 41., 2004, Campo Grande. Anais... Campo Grande: Sociedade Brasileira de Zootecnia, [2004]. CD ROOM. Nutrição de Ruminantes. FOR 287.

STATISTICAL ANALYSES SYSTEM - SAS. SAS user's guide: statistics. 5.ed. Cary: 1985. 956p.

SILVA, D.J. Análise dos alimentos (Métodos químicos e biológicos). 2.ed. Viçosa, MG: Universidade Federal de Viçosa, 1998. 166p.

TOSI, H. Ensilagem de gramíneas tropicais sob diferentes tratamentos. Botucatu: Universidade Estadual Paulista, 1973. 107p. Tese (Doutorado em Zootecnia) - Universidade Estadual Paulista, 1973

TOSI, P.; MATTOS, W.R.S.; TOSI, H. et al. Avaliação do capimelefante (Pennisetum purpureum Schum.) cultivar Taiwan A-148, ensilado com diferentes técnicas de redução de umidade. Revista Brasileira de Zootecnia, v.28, n.5, p.947-954, 1999.

Van SOEST, P.J. Nutritional ecology of ruminant. Corvallis: O \& B Books, 1994. 476p.

VILELA, D. Aditivos para silagem de plantas de clima tropical. In: REUNIÃO ANUAL DA SOCIEDADE BRASILEIRA DE ZOOTECNIA, 35., 1998, Botucatu. Anais... Botucatu: Sociedade Brasileira de Zootecnia, 1998. p.73.

WOOLFORD, M.K. The silage fermentation. New York: Marcel Dekker, 1984. 350p.

Recebido em: 11/12/03 Aceito em: 09/03/05 